\title{
Reading and proclaiming the Birth Narratives from Luke and Matthew: A study in empirical theology amongst curates and their training incumbents employing the SIFT method
}

\begin{tabular}{|c|c|}
\hline $\begin{array}{l}\text { Authors: } \\
\text { Leslie J. Franc } \\
\text { Greg Smith }{ }^{1,2}\end{array}$ & \\
\hline $\begin{array}{l}\text { Affiliations: } \\
{ }^{1} \text { Warwick Reli } \\
\text { Education Res } \\
\text { University of } \\
\text { United Kingd }\end{array}$ & $\begin{array}{l}\text { gions and } \\
\text { earch Unit, } \\
\text { Narwick, } \\
\text { m }\end{array}$ \\
\hline $\begin{array}{l}{ }^{2} \text { Department } \\
\text { Testament St } \\
\text { University of } \\
\text { South Africa }\end{array}$ & $\begin{array}{l}\text { of New } \\
\text { dies, } \\
\text { retoria, }\end{array}$ \\
\hline $\begin{array}{l}\text { Note: } \\
\text { Prof. Dr Leslie } \\
\text { The Revd Gre } \\
\text { participating } \\
\text { fellow in the } \\
\text { Theology and } \\
\text { directed by Pr } \\
\text { G. van Aarde, } \\
\text { Professor at } t \\
\text { Theology of th } \\
\text { of Pretoria, Sc }\end{array}$ & $\begin{array}{l}\text { J. Francis and } \\
\text { Smith are } \\
\text { s a research } \\
\text { roject Biblical } \\
\text { Hermeneutics } \\
\text { of. Dr Andries } \\
\text { Honorary } \\
\text { he Faculty of } \\
\text { ee University } \\
\text { uth Africa. }\end{array}$ \\
\hline $\begin{array}{l}\text { Corresponder } \\
\text { Leslie Francis }\end{array}$ & ce to: \\
\hline $\begin{array}{l}\text { Email: } \\
\text { leslie.francis@ }\end{array}$ & warwick.ac.uk \\
\hline $\begin{array}{l}\text { Postal addres } \\
\text { Warwick Relig } \\
\text { Education Res } \\
\text { Institute of Ed } \\
\text { The Universit } \\
\text { Coventry CV4 } \\
\text { United Kingdo }\end{array}$ & $\begin{array}{l}\text { s: } \\
\text { ions and } \\
\text { earch Unit, } \\
\text { ucation, } \\
\text { of Warwick } \\
\text { 7AL, } \\
\text { m }\end{array}$ \\
\hline $\begin{array}{l}\text { Dates: } \\
\text { Received: } 30 \\
\text { Accepted: } 16 \\
\text { Published: } 30\end{array}$ & $\begin{array}{l}\text { Apr. } 2013 \\
\text { May } 2013 \\
\text { July } 2013\end{array}$ \\
\hline Read online: & \\
\hline 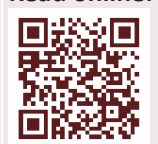 & $\begin{array}{l}\text { Scan this QR } \\
\text { code with your } \\
\text { smart phone or } \\
\text { mobile device } \\
\text { to read online. }\end{array}$ \\
\hline
\end{tabular}

Drawing on Jungian psychological type theory, the SIFT method of biblical hermeneutics and liturgical preaching suggests that the reading and proclaiming of scripture reflects the psychological type preferences of the reader and preacher. This thesis is examined amongst two samples of curates and training incumbents $(N=23,27)$, serving in one Diocese of the Church of England, who completed the Myers-Briggs Type Indicator. Firstly, the narrative of the shepherds from Luke was discussed by groups organised according to scores on the perceiving process. In accordance with the theory, sensing types focused on details in the passage, but could reach no consensus on the larger picture, and intuitive types quickly identified an imaginative, integrative theme, but showed little interest in the details. Secondly, the narrative of the massacre of the infants from Matthew was discussed by groups organised according to scores on the judging process. In accordance with theory, the thinking types identified and analysed the big themes raised by the passage (political power, theodicy, obedience), whilst the feeling types placed much more emphasis on the impact that the passage may have on members of the congregation mourning the death of their child or grandchild.

\section{Introduction}

The SIFT method of biblical hermeneutics and liturgical preaching is grounded in three specific principles of empirical theology (Francis \& Village 2008). The first principle affirms that information of theological importance is derived from the practice of systematic observation of God's world. This practice carries dominical authority grounded in the gospel account of Jesus' instruction to his followers to go and to observe the sower, and to note systematically the correlation between the different qualities of the ground and the fruit yielded. Behind this instruction stands profound insight into the doctrine of creation and into the Kingdom of God. The SIFT method has its origins in empirical observation.

The second principle affirms that theologians have a responsibility to take seriously the scientifically-grounded theories and methods of observation and analysis developed in secular disciplines and, where appropriate, to integrate these theories and methods within good practice in theology itself. This leads both to fruitful interdisciplinary enquiry and to the intradisciplinary adoption of such approaches within the theological academy (see Cartledge 1999). The SIFT method has developed from both interdisciplinary and intradisciplinary enquiry.

The third principle affirms that insights generated by empirical enquiry need to be thoroughly tested within other branches of the theological academy. The SIFT method has been contextualised within the framework of systematic theology and rooted within the doctrine of creation. The SIFT method flows from a theology of individual differences that argues that the connection between humankind and the divine image established in Genesis 1:27 implies that certain levels of human difference reflect the divine image and are fundamental to the intentionality of the divine creator. Such differences embrace those of sex differences, ethnic differences and differences in psychological type.

The notion of differences in psychological type as reflecting the divine image rests on analysis distinguishing between those aspects and characteristics of the human psyche that are consistent with the doctrine of creation (fundamental differences like sex and ethnicity) and those that are

How to cite this article: Francis, L.J. \& Smith, G. 2013, 'Reading and proclaiming the Birth Narratives from Luke and Matthew: A study in empirical theology amongst curates and their training incumbents employing the SIFT method', HTS Teologiese Studies/Theological Studies 69(1), Art. \#2001, 13 pages. http://dx.doi.org/10.4102/hts.v69i1.2001

Copyright: @ 2013. The Authors. Licensee: AOSIS OpenJournals. This work is licensed under the Creative Commons Attribution License. 
consistent with the doctrine of the fall (reflecting corruption) and with the doctrine of salvation (reflecting transformation in Christ). Fundamental psychological differences (on a level with sex and ethnicity) are discussed by Carl Jung (1971) under the theme of 'psychological type'. The SIFT method takes its name from the four key functions proposed by psychological type theory, namely sensing (S), intuition (I), feeling $(\mathrm{F})$, and thinking $(\mathrm{T})$.

Jungian psychological type theory proposes individual differences in the two core psychological processes of perceiving and evaluating or judging that are rooted in the human condition (see Francis 2005). The perceiving process is the irrational process concerned with the ways in which information is gathered; the perceiving process makes no judgement about that data. The evaluating or judging process is the rational process concerned with the ways in which information is evaluated. According to the theory, the perceiving process is expressed through two different approaches: the sensing function (S) concerned with the detail' and the intuitive function (I) concerned with 'the big picture'. The evaluating or judging process is also expressed through two different approaches: the feeling function (F) concerned with 'subjective values' and the thinking function (T) concerned with 'objective logic'. According to the theory most individuals have access to all four functions, but naturally prefer one perceiving function over the other (sensing or intuition) and naturally prefer one evaluating or judging function over the other (thinking or feeling). The analogy is with human handedness where most individuals prefer one hand over the other and develop their skills with that hand, to the comparative neglect of the other.

In its understanding of type dynamics, Jungian psychological type theory takes the notion of the differential development of the four psychological functions one step further. Not only do individuals tend to prefer one perceiving function over the other, and one judging function over the other, but they also tend to develop more strongly either their preferred perceiving function (sensing or intuition) or their preferred judging function (thinking or feeling) over the other. In this area one function becomes visible as the individual's dominant function, and it is this function that shapes the dominant perspective on life. Thus dominant sensing shapes the practical person, dominant intuition shapes the imaginative and creative person, dominant thinking shapes the logical and strategic person, and dominant feeling shapes the humane and caring person.

Psychological type theory has been operationalised by several type indicators, temperament sorters, or type scales, including the Myers-Briggs Type Indicator (Myers \& McCaulley 1985), the Keirsey Temperament Sorter (Keirsey \& Bates 1978), and the Francis Psychological Type Scales (Francis 2005). In addition to distinguishing between the two perceiving functions (sensing and intuition) and the two judging functions (feeling and thinking), these instruments also distinguish between two orientations (introversion and extraversion) and two attitudes toward the outer world (judging and perceiving). The orientations and the attitudes are not, however, relevant to the SIFT method of biblical hermeneutics and liturgical preaching.

The SIFT method of biblical hermeneutics and liturgical preaching takes the view that individuals' preferred psychological functions shape how different readers read the text in different ways, and how different readers perceive the revelation of God through the lens of their dominant type preferences. The theology of individual differences would urge the people of God to take these different reader perspectives seriously in order to develop a rounded and composite view of God's revelation within the contemporary context.

In order to develop this composite perspective, the SIFT method addresses, to each passage of scripture, the four sets of questions posed by the four psychological functions of sensing and intuition (the two perceiving functions) and of feeling and thinking (the two evaluating or judging functions) in that set order. The two perceiving functions (sensing and intuition) are applied first, since the perceiving process is concerned with gathering information and ideas. This is the irrational process unconcerned with making judgements or with formulating evaluations. The two evaluating or judging functions (feeling and thinking) are applied second, since the judging process is concerned with evaluating information and ideas. Both feeling and thinking are rational functions.

The first step in the SIFT method is to address the sensing perspective. It is the sensing perspective which gets to grips with the text itself and which gives proper attention to the details of the passage and may wish to draw on insights of historic methods of biblical scholarship in order to draw in 'facts' from other parts of the Bible. The first set of questions asks: How does this passage speak to the sensing function? What are the facts and details? What is there to see, to hear, to touch, to smell, and to taste?

The second step in the SIFT method is to address the intuitive perspective. It is the intuitive perspective which relates the biblical text to wider issues and concerns. The second set of questions asks: How does this passage speak to the intuitive function? What is there to speak to the imagination, to forge links with current situations, to illuminate issues in our lives?

The third step in the SIFT method is to address the feeling perspective. It is the feeling perspective which examines the human interest in the biblical text and learns the lessons of God for harmonious and compassionate living. The third set of questions asks: How does this passage speak to the feeling function? What is there to speak about fundamental human values, about the relationships between people, and about what it is to be truly human?

The fourth step in the SIFT method is to address the thinking perspective. It is the thinking perspective which examines the theological interest in the biblical text and which reflects rationally and critically on issues of principle. The fourth set of questions asks: How does this passage speak to the 
thinking function? What is there to speak to the mind, to challenge us on issues of truth and justice, and to provoke profound theological thinking?

Whilst the SIFT method of biblical hermeneutics and liturgical preaching had its origins in extrapolation from Jungian psychological type theory, a small (but growing) body of empirical research has begun to interrogate and to underpin this approach, drawing on both quantitative and qualitative research traditions. Within the quantitative research traditions some of the insights of the SIFT approach were anticipated in a pioneering study reported by Bassett, Mathewson and Gailitis (1993) who examined the link between preferred interpretations of scripture and psychological preferences established partly by psychological type theory and partly by a measure of problem solving styles. Participants were asked to read four passages from New Testament epistles and then offered a choice of interpretations that were intended to express preferences for 'thinking' or for 'feeling' (as defined by psychological type theory) and preferences for 'collaborative', for 'deferring', or for 'independent' (as defined by this problem solving typology). Although mixing two personality models makes the results difficult to interpret, the data provided some support for a link between psychological type preference and choice of interpretations. Most obviously those classed as feeling types showed a preference for feeling-type interpretations.

In the second quantitative study, Village and Francis (2005) invited a sample of 404 lay adult Anglicans from 11 different churches to read a healing story from Mark's Gospel and then to choose between pairs of interpretative statements designed to distinguish between the perceiving functions (sensing and intuition) or between the evaluating or judging functions (thinking and feeling). The participants also completed the Keirsey Temperament Sorter (Keirsey \& Bates 1978) as a measure of psychological type. The data demonstrated that, when forced to choose between contrasting options, participants preferred interpretations that matched their psychological type preferences in both the perceiving process and the evaluating or judging process.

In the third quantitative study, Francis, Robbins and Village (2009) invited a sample of 389 experienced preachers to read Mark 1:29-39 and to record their evaluations of the four reflections on this passage proposed originally by Francis (1997) and which were derived from the SIFT method of biblical hermeneutics and liturgical preaching. The participants also completed the 126-item Form G (Anglicised) of the Myers-Briggs Type Indicator (Myers \& McCaulley 1985) as a measure of psychological type. The data demonstrated that preachers were four times more likely to prefer a sensing interpretation of the text rather than a thinking interpretation, emphasising the richness of the narrative rather than facing the theological questions posed by it. Moreover, there was little evidence to suggest that preachers were less likely to appreciate interpretations consonant with their less preferred function than those consonant with their most preferred or dominant function. In this sense, the SIFT method should be accessible to preachers of all psychological types.
In the fourth quantitative study, Village (2010) invited a sample of 718 recently ordained Anglican clergy serving in England, Ireland, Scotland and Wales to read the healing story from Mark 9:14-29 and to select between interpretative statements designed to appeal to particular psychological type preferences. The participants also completed the Francis Psychological Type Scale (Francis 2005) as a measure of psychological type. The data demonstrated that, after controlling for differences in biblical conservatism, preferences for interpretation were significantly correlated with psychological type function preferences in both the perceiving process and the judging process. These findings confirmed and expanded the findings from the earlier study amongst Anglican lay people reported by Village and Francis (2005).

Within the qualitative research tradition, Francis (2010) invited two different groups of Anglican preachers (24 licensed readers in England and 22 licensed clergy in Northern Ireland) to work in groups defined by their dominant psychological type preferences (dominant sensers, dominant intuitives, dominant thinkers and dominant feelers). Within these dominant type groups they were asked to prepare a presentation on Mark 6:34-44 (the feeding of the five thousand). In his analysis of their presentations, Francis distinguished and displayed the four clear voices of the dominant type perspectives.

In the second qualitative study, Francis and Jones (2011) focused on Mark 16:1-8 and Matthew 28:1-15 (resurrection narratives), working with two different groups (26 ministry training candidates, and 21 Anglican clergy and readers). On this occasion Francis and Jones developed a twostage process. In stage one, the participants were divided according to the perceiving process (sensing and intuition) and invited to discuss the Marcan narrative. In stage two, the participants were divided according to the judging process (thinking and feeling) and invited to discuss the Matthean narrative. In their analysis of the presentations made by the different groups, Francis and Jones (2011) distinguished and displayed the four clear voices of sensing, intuition, thinking and feeling.

In the third qualitative study, Francis (2012a) focused on Mark 11:11-21 (the cleansing of the temple and the incident of the fig tree), working with three different groups (31 Anglican clergy, a group of 14 clergy and lay preachers, and a mixed group of 47 lay people and clergy). Instead of inviting the participants to work in dominant type groups, on this occasion Francis invited the participants to discuss the passage in two stages. For stage one, the participants were divided according to the perceiving process, distinguishing between groups of sensing types and groups of intuitive types. For stage two, the participants were divided according to the evaluating or judging process, distinguishing between groups of feeling types and groups of thinking types. In his analysis of the presentations made by different groups, Francis (2012a) distinguished and displayed the four clear voices of sensing, intuition, thinking and feeling. 
In the fourth qualitative study, Francis (2012b) focused on John 6:4-22 (the Johannine feeding narrative), working with two groups of ministry training candidates (one group of 13 women and 6 men, and one group of 2 women and 5 men). On this occasion Francis invited the participants to discuss the passage in two stages. In stage one, the participants were divided according to the perceiving process and asked to accomplish three tasks: to reflect on the passage, to note issues of interest to them, and to prepare material for preaching. In stage two, the participants were divided according to the judging process and asked to accomplish three tasks: to reflect on the passage, to note the issues raised by the passage and to prepare material for preaching. Once again the presentations made by the different groups revealed clear differences between sensing types and intuitive types and between feeling types and thinking types.

In the fifth qualitative study, Francis (2013) focused on Mark 1:2-8 and Luke 3:2b-20 (John the Baptist), working with a group of 8 people associated with their local church and attending a church-based study group ( 3 women and 5 men). Firstly, the Marcan narrative (concentrating on the imagery of John the Baptist) was discussed by two groups organised according to scores on the perceiving process (4 sensing types and 4 intuitive types). The data confirmed the propensity for ordinary readers who preferred sensing to concentrate on the details and practical realities of the narrative, and for those who preferred intuition to focus on the bigger picture. Secondly, the Lucan narrative (concentrating on the teaching of John the Baptist) was discussed by two groups organised according to scores on the judging process ( 3 thinking types and 5 feeling types). The data confirmed the propensity for ordinary readers who preferred feeling to identify with the human concerns displayed in the narrative, and for those who preferred thinking to analyse the narrative and to identify the theological issues.

\section{Method}

\section{Research question}

Against this background, the aim of the present study was to build on the recent qualitative research tradition established by Francis (2010), Francis and Jones (2011) and Francis (2012a, 2012b, 2013) in order to explore how psychological type preferences are reflected in approaches to the birth narratives presented in Luke 2:8-20 (see Appendix 1) and Matthew 2:13-20 (see Appendix 2). The hypothesis was that participants who are largely naive about the SIFT method, when placed in groups of individuals sharing the same psychological type preferences, will generate interpretations of (or reflections on) scripture broadly consistent with their personal psychological type style.

\section{Procedure}

In the context of two residential programmes (the first conducted during January 2011 and the second conducted during January 2012), the participants were invited to complete a recognised measure of psychological type and to experience working in groups structured on the basis of psychological type theory. Reading, reflecting on and proclaiming scripture was an integral part of the group experience.

\section{Measure}

Psychological type was assessed by the 126-item Form G (Anglicised) of the Myers-Briggs Type Indicator (Myers \& McCaulley 1985). This instrument uses a force-choice questionnaire format to indicate preferences between the two orientations (extraversion or introversion), the two perceiving functions (sensing or intuition), the two judging functions (feeling or thinking), and the two attitudes (judging or perceiving). The preference between introversion and extraversion is assessed by questions like: When you are with a group of people, would you rather: (1) join in the talk of the group (extraversion), or (2) talk with one person at a time (introversion)? The preference between sensing and intuition is assessed by questions like: Would you rather have as a friend: (1) someone who is always coming up with new ideas (intuition), or (2) someone who has both feet on the ground (sensing)? The preference between feeling and thinking is assessed by questions like: Do you more often let: (1) your heart rule your head (feeling), or (2) your head rule your heart (thinking)? The preference between judging and perceiving is assessed by questions like: When you go somewhere for the day, would you rather: (1) plan what you will do and when (judging), or (2) just go (perceiving)? Broad support for the reliability and validity of the instrument is provided in the international literature as summarised by Francis and Jones (1999) who additionally demonstrated the stability of the scale properties of the instrument amongst a sample of 429 adult churchgoers. In another study amongst 863 Anglican clergy, Francis et al. (2007) reported the following alpha coefficients: extraversion, .80 ; introversion, .79; sensing, .87; intuition, .82; thinking, .79; feeling, .72; judging, .85 ; perceiving, 86 .

\section{Analysis}

The groups (structured on the basis of psychological type theory) were assigned specific tasks (defined below), they were invited to work on these tasks and to agree on a common presentation of their conclusions. These presentations were both written in text form and spoken in plenary when the groups reassembled to share their conclusions with each other. It is these written texts and these spoken presentations (carefully noted by the authors) that provide the data for analysis. The results section of the article presents a summary of the written and spoken presentations, in order to allow the different perspectives emphasised by the groups to become clearly visible.

\section{Study one: Results Participants}

Twelve sets of training incumbents and their curates accepted the invitation to participate in the residential programme held in January 2011. Illness prevented one curate from attending, resulting in participation from 11 curates and 12 incumbents 
(8 women and 15 men). Table 1 presents the psychological type profile of the 23 participants. This table is presented in the conventional format of 'type tables' employed within the international research literature on psychological type in order to facilitate comparison with other studies in the field. The key information from the table for the present study concerns the dichotomous preferences, the dominant types, and the 16 complete types. The dichotomous preferences describe a group characterised by preference for introversion

TABLE 1: Type distribution of curates and training incumbents, 2011.

\begin{tabular}{|c|c|c|c|c|c|c|}
\hline \multicolumn{4}{|c|}{ The Sixteen Complete Types } & \multicolumn{3}{|c|}{ Dichotomous Preferences } \\
\hline ISTJ & ISFJ & INFJ & INTJ & $E$ & $n=10$ & $(43.5 \%)$ \\
\hline$n=4$ & $n=1$ & $n=2$ & $n=2$ & 1 & $n=13$ & $(56.5 \%)$ \\
\hline \multirow[t]{2}{*}{$(17.4 \%)$} & $(4.3 \%)$ & $(8.7 \%)$ & $(8.7 \%)$ & & & \\
\hline & & & & S & $n=9$ & $(39.1 \%)$ \\
\hline+++++ & ++++ & +++++ & +++++ & N & $n=14$ & $(60.9 \%)$ \\
\hline++++ & & +++ & +++ & & & \\
\hline+++++ & & & & $\mathrm{T}$ & $n=10$ & $(43.5 \%)$ \\
\hline \multirow[t]{3}{*}{++} & & & & $\mathrm{F}$ & $n=13$ & $(56.5 \%)$ \\
\hline & & & & J & $n=13$ & $(56.5 \%)$ \\
\hline & & & & P & $n=10$ & $(43.5 \%)$ \\
\hline
\end{tabular}

\begin{tabular}{|c|c|c|c|c|c|c|}
\hline \multirow{3}{*}{$\begin{array}{l}\text { ISTP } \\
\boldsymbol{n}=\mathbf{0} \\
(0.0 \%)\end{array}$} & \multirow{3}{*}{$\begin{array}{l}\text { ISFP } \\
\boldsymbol{n}=\mathbf{0} \\
(0.0 \%)\end{array}$} & \multirow{3}{*}{$\begin{array}{l}\text { INFP } \\
n=3 \\
(13.0 \%)\end{array}$} & \multicolumn{4}{|l|}{ INTP } \\
\hline & & & $n=1$ & \multicolumn{3}{|c|}{ Pairs and Temperaments } \\
\hline & & & $(4.3 \%)$ & & & \\
\hline & & & & IJ & $n=9$ & $(39.1 \%)$ \\
\hline & & +++++ & ++++ & IP & $n=4$ & $(17.4 \%)$ \\
\hline & & +++++ & & EP & $n=6$ & $(26.1 \%)$ \\
\hline & & +++ & & EJ & $n=4$ & $(17.4 \%)$ \\
\hline & & & & ST & $n=6$ & $(26.1 \%)$ \\
\hline & & & & SF & $n=3$ & $(13.0 \%)$ \\
\hline & & & & $N F$ & $n=10$ & $(43.5 \%)$ \\
\hline ESTP & ESFP & ENFP & ENTP & NT & $n=4$ & $(17.4 \%)$ \\
\hline$n=1$ & $n=1$ & $n=4$ & $n=0$ & & & \\
\hline \multirow[t]{2}{*}{$(4.3 \%)$} & $(4.3 \%)$ & $(17.4 \%)$ & $(0.0 \%)$ & SJ & $n=7$ & $(30.4 \%)$ \\
\hline & & & & SP & $n=2$ & $(8.7 \%)$ \\
\hline \multirow[t]{7}{*}{ ++++ } & ++++ & +++++ & & NP & $n=8$ & $(34.8 \%)$ \\
\hline & & +++++ & & NJ & $n=6$ & $(26.1 \%)$ \\
\hline & & +++++ & & & & \\
\hline & & ++ & & TJ & $n=8$ & $(34.8 \%)$ \\
\hline & & & & TP & $n=2$ & $(8.7 \%)$ \\
\hline & & & & FP & $n=8$ & $(34.8 \%)$ \\
\hline & & & & FJ & $n=5$ & $(21.7 \%)$ \\
\hline ESTJ & ESFJ & ENFJ & ENTJ & IN & $n=8$ & $(34.8 \%)$ \\
\hline$n=1$ & $n=1$ & $n=1$ & $n=1$ & EN & $n=6$ & $(26.1 \%)$ \\
\hline \multirow[t]{2}{*}{$(4.3 \%)$} & $(4.3 \%)$ & $(4.3 \%)$ & $(4.3 \%)$ & IS & $n=5$ & $(21.7 \%)$ \\
\hline & & & & ES & $n=4$ & $(17.4 \%)$ \\
\hline \multirow[t]{5}{*}{ ++++ } & ++++ & ++++ & ++++ & & & \\
\hline & & & & ET & $n=3$ & $(13.0 \%)$ \\
\hline & & & & $\mathrm{EF}$ & $n=7$ & $(30.4 \%)$ \\
\hline & & & & IF & $n=6$ & $(26.1 \%)$ \\
\hline & & & & IT & $n=7$ & $(30.4 \%)$ \\
\hline
\end{tabular}

\begin{tabular}{|c|c|c|c|c|c|c|c|c|c|}
\hline \multicolumn{3}{|c|}{ Jungian Types (E) } & \multicolumn{3}{|c|}{ Jungian Types (I) } & \multicolumn{3}{|c|}{ Dominant Types } & \multirow{6}{*}{ 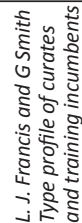 } \\
\hline & $n$ & $\%$ & & $n$ & $\%$ & & $n$ & $\%$ & \\
\hline E-TJ & 2 & 8.7 & I-TP & 1 & 4.3 & Dt.T & 3 & 13.0 & \\
\hline E-FJ & 2 & 8.7 & I-FP & 3 & 13.0 & Dt.F & 5 & 21.7 & \\
\hline ES-P & 2 & 8.7 & IS-J & 5 & 21.7 & Dt.S & 7 & 30.4 & \\
\hline EN-P & 4 & 17.4 & IN-J & 4 & 17.4 & Dt.N & 8 & 34.8 & \\
\hline
\end{tabular}

Note: $N=23+=1 \%$ of $N$.
(13) over extraversion (10); preference for intuition (14) over sensing (9); preference for feeling (13) over thinking (10); and preference for judging (13) over perceiving (10). The dominant type preferences show the following pattern: intuition (8), sensing (7), feeling (5), and thinking (3). The 16 complete types show that the most frequently represented types were ISTJ (4) and ENFP (4).

\section{Perceiving process}

\section{Procedure}

The participants were divided into three groups: seven participants who recorded highest preference scores on sensing $(57,51,37,25,25,19,15)$; seven participants who recorded highest preference scores on intuition $(39,37,35,33$, $31,29,17)$; and seven participants who recorded lower scores on intuition, together with two participants who recorded low scores on sensing. The participants were invited to read Luke 2:8-20 and then reflect on the following questions: What do you see and what do you perceive in this passage: this is now the first Sunday after Christmas, what would you preach from this passage? The following analysis concentrates on the two groups that contained the highest preference scores on sensing and the highest preference scores on intuition.

\section{Findings}

The group of high scoring sensing types found the task difficult to begin with and puzzled over the meaning of 'see' and 'perceive'. What they saw in the passage was something that is so familiar. They saw the Christmas nativity play full of primary school children with tea towels on their heads. They heard the familiar words of the 'Gloria' sung or said in the communion service. They recalled having heard countless sermons preached on the passage. They saw it as a very visual passage and detailed the component parts: they saw the shepherds looking terrified, and they saw the angels looking glorious. They heard the component words, like 'good news', 'great joy' and 'all the people'. They felt the sense of immediacy in the passage and heard the shepherds say one to another, 'Let us go to Bethlehem'. They saw a historic event that really happened. They saw the narrative as a fact and they saw the shepherds' response as clear, realistic and understated.

The group of high scoring sensing types perceived in the text the revelation of God to ordinary people through the baby lying in the manger. The revelation was broadcast not by one angel alone, but by the whole company of the heavenly host.

The group had come at the passage from attraction to so many and to such diverse details in the text that there was no chance of reaching consensus on the theme for preaching. One wanted to develop the text 'Let's go to Bethlehem and see this thing'. Another wanted to explore the notion of 'glory'. Another wanted to focus on the shepherds as normal earthy people. But then time ran out.

The group of high scoring intuitive types quickly generated a sense of excitement about the passage and this excitement 
produced a series of imaginative links and connections from the passage. The overall theme was the meeting of the earthly and the heavenly. Here was a transcendent narrative out of time and out of history. Here was a hugely creative canvas of contrasts and movements: from darkness to light, from past to present, from heaven to earth. Here were notions of discomfort and separation, of outsiders and vulnerability, of shepherds and the heavenly host, of positive and negative. All of this led to discussion of mystery, of the numinous, and of God's revelation to the world. Overall the group of high scoring intuitive types made little reference to the passage of scripture, but drew easily on their wider experience of the Lucan narrative.

This group had come to the passage with a shared attraction to the excitement of exploring the transcendent theme of the meeting of the earthly and the heavenly. In their preaching they wanted to enable their listeners to catch the same vision, to share the same excitement, to enter into the experience shared by the shepherds, and to respond to God's revelation given to the world in Bethlehem.

\section{Judging process}

\section{Procedure}

The participants were divided into three groups: seven participants who recorded highest preferences on thinking $(33,27,27,23,13,9,9)$; eight participants who recorded highest preferences on feeling $(35,29,29,25,25,21,19,19)$; and five participants who recorded lower scores on feeling, together with three participants who recorded lower scores on thinking. The participants were invited to read Matthew 2:13-20 and to reflect on the two following questions: It is Boxing Day and this is the set text, what would be your three central points? Would this change if you knew, in your congregation that morning, there was Barbara who had just lost her two-year-old grandson to cancer? The following analysis concentrates on the two groups that contained the highest preference scores on thinking and with the highest preference scores on feeling.

\section{Findings}

The group of high scoring thinking types began with the text of scripture and quickly identified and analysed a number of theologically profound themes raised by the passage. The first theme identified was that of obedience: Mary and Joseph exemplified obedience to God by following his command to flee, however uncomfortable it was to turn their back on their home. The second theme identified was that of theodicy: why did God allow the suffering of the many infants when he could have warned all their parents to lead them to safety? The third theme identified was that of abuse of political power: Herod abused his power by taking extreme measures to remove political threat to his dynasty. Such abuse of political power has been evident throughout the ages and remains evident today. The fourth theme identified was that of incarnation: the arrival of God in the world causes a hostile reaction. The high scoring thinking types agreed that all four themes were appropriate for the Boxing Day service.

This group considered Barbara's presence in the congregation and discussed changes that could be made to reflect sensitivity to her situation. The first option would involve changing the reading. The group was adamant that this was not a viable option. The lectionary forces engagement with uncomfortable parts of scripture and to avoid such passages (even out of respect for Barbara) would be to take a Marcionite view of sacred text. The second option would involve changing the theological emphases preached form the passage. The group was adamant this was not a viable option either. Theological truths must remain constant. This group considered that the passage could be used to bring comfort to Barbara, emphasising that, although these infants die, this does not mean that God does not love them. They resolved to go ahead with the Gospel reading and with their preaching; but they would take the opportunity to mention Barbara's situation in the notices and in the prayers.

The group of high scoring feeling types began with Barbara and with discussing Barbara's situation, Barbara's feelings, and Barbara's need. They recognised that Barbara might find hearing that passage about the massacre of the infants read in the service very distressing. They resolved that they would want to see Barbara before the service, advise her concerning the theme for Boxing Day, and give her the opportunity not to attend the service. They went on from this point, however, to recognise that Barbara may well not have been the only person in the Boxing Day congregation troubled by the theme of the passage from Matthew. There may well be other people present for whom not only the massacre of the infants, but even the celebration of the holy birth may have triggered uncomfortable associations and uncomfortable memories and feelings. Christmas can be an uncomfortable time, when everyone in the Church is talking and celebrating birth, for those who are mourning death or who long for children and for family life.

This group never got round to close engagement with the passage, but dealt with the larger theme of the Christmas gospel message, the theme that 'God cares'. Human life is fragile, but God cares enough to be there at the heart of life. Human birth is risky, but God cares enough to be born at a dangerous time in history and when there was not even enough room for his birth in the inn.

\section{Study two: Results Participants}

Twelve sets of training incumbents and their curates, together with three curates unaccompanied by their training incumbents, accepted the invitation to participate in the residential programme held in January 2012. The participants comprised 6 women and 21 men. Table 2 presents the psychological type profile of the 27 participants. The key information from the table for the present study concerns the dichotomous preferences, the dominant types, and the 
16 complete types. The dichotomous preferences describe a group characterised by preference for introversion (19) over extraversion (8), preference for intuition (15) over sensing (12), preference for feeling (17) over thinking (10) and preference for judging (18) over perceiving (9). The dominant type preferences show the following pattern: intuition (9), sensing (9), feeling (5), and thinking (4). The 16 complete types show that the most frequently represented types were ISFJ (5), ISTJ (4) and INFJ (4).

TABLE 2: Type distribution of curates and training incumbents, 2012.

\begin{tabular}{|c|c|c|c|c|c|c|}
\hline \multicolumn{4}{|c|}{ The Sixteen Complete Types } & \multicolumn{3}{|c|}{ Dichotomous Preferences } \\
\hline$\overline{\text { ISTJ }}$ & ISFJ & INFJ & INTJ & $E$ & $n=8$ & $(29.6 \%)$ \\
\hline$n=4$ & $n=5$ & $n=4$ & $n=1$ & 1 & $n=19$ & $(70.4 \%)$ \\
\hline \multirow[t]{2}{*}{$(14.4 \%)$} & $(18.5 \%)$ & $(14.8 \%)$ & $(3.7 \%)$ & & & \\
\hline & & & & S & $n=12$ & $(44.4 \%)$ \\
\hline++++ & ++++ & +++++ & ++++ & N & $n=15$ & $(55.6 \%)$ \\
\hline+++++ & +++++ & +++++ & & & & \\
\hline \multirow[t]{4}{*}{ +++++ } & +++++ & +++++ & & $\mathrm{T}$ & $n=10$ & $(37.0 \%)$ \\
\hline & ++++ & & & $\mathrm{F}$ & $n=17$ & $(63.0 \%)$ \\
\hline & & & & J & $n=18$ & $(66.7 \%)$ \\
\hline & & & & $P$ & $n=9$ & $(33.3 \%)$ \\
\hline
\end{tabular}

ISTP ISFP INFP INTP

$n=1 \quad n=0 \quad n=3 \quad n=1$

$(3.7 \%) \quad(0.0 \%) \quad(11.1 \%) \quad(3.7 \%)$

$+++$

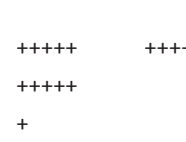

Pairs and Temperaments

IJ $n=14$

$(51.9 \%)$

EP $n=4$

EJ $n=4$

$(14.8 \%)$

$(14.8 \%)$

ST $n=6$

$(22.2 \%)$

SF $\quad n=6$

NF $n=11$

ESTP

$\boldsymbol{n}=\mathbf{0}$

ESFP

ENFP

ENTP

NT $n=4$

$(22.2 \%)$

$(40.7 \%)$

$(14.8 \%)$

$(0.0 \%)$

$(0.0 \%)$

$n=1$

$(3.7 \%)$

SJ $n=11$

$(40.7 \%)$

(3.7\%)

$(29.6 \%)$

+++++ NP $n=8$

NJ $n=7$

(25.9\%)

$+$

TJ $n=7 \quad(25.9 \%)$

TP $n=3 \quad(11.1 \%)$

FP $\quad n=6 \quad(22.2 \%)$

FJ $n=11 \quad(40.7 \%)$

$\begin{array}{llllccc}\text { ESTJ } & \text { ESFJ } & \text { ENFJ } & \text { ENTJ } & \text { IN } & n=9 & (33.3 \%) \\ \boldsymbol{n = 1} & \boldsymbol{n = 1} & \boldsymbol{n = 1} & \boldsymbol{n = 1} & \text { EN } & n=6 & (22.2 \%) \\ (3.7 \%) & (3.7 \%) & (3.7 \%) & (3.7 \%) & \text { IS } & n=10 & (37.0 \%) \\ & & & & \text { ES } & n=2 & (7.4 \%) \\ +++ & ++++ & ++++ & ++++ & & & \\ & & & & \text { ET } & n=3 & (11.1 \%) \\ & & & & \text { EF } & n=5 & (18.5 \%) \\ & & & & \text { IF } & n=12 & (44.4 \%) \\ & & & & \text { IT } & n=7 & (25.9 \%)\end{array}$

\begin{tabular}{|c|c|c|c|c|c|c|c|c|c|}
\hline \multicolumn{3}{|c|}{ Jungian Types (E) } & \multicolumn{3}{|c|}{ Jungian Types (I) } & \multicolumn{3}{|c|}{ Dominant Types } & \multirow{2}{*}{ 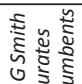 } \\
\hline & $n$ & $\%$ & & $n$ & $\%$ & & $n$ & $\%$ & \\
\hline E-TJ & 2 & 7.4 & I-TP & 2 & 7.4 & Dt.T & 4 & 14.8 & ธิ์ \\
\hline E-FJ & 2 & 7.4 & I-FP & 3 & 11.1 & Dt.F & 5 & 18.5 & \\
\hline ES-P & 0 & 0.0 & IS-J & 9 & 33.3 & Dt.S & 9 & 33.3 & \\
\hline EN-P & 4 & 14.8 & IN-J & 5 & 18.5 & Dt.N & 9 & 33.3 & ذي \\
\hline
\end{tabular}

Note: $N=27+=1 \%$ of $N$.

\section{Perceiving Process}

\section{Procedure}

Participants were divided into four groups: six participants who recorded highest preference scores on sensing $(33,31$, $29,23,21,17)$; six participants who recorded lower preference scores on sensing $(15,15,13,11,5,1)$; seven participants who recorded highest preferences scores on intuition $(45,43,41$, $31,27,25,25)$; and eight participants who recorded lower preference scores on intuition $(19,17,15,9,7,3,3,3)$. The participants were invited to read Luke 2:8-20 and then reflect on the following task: This is the first Sunday after Christmas and you are preaching. What do you see in this passage and what do you want others to see? The following analysis concentrates on each of these four groups in turn.

\section{Findings}

The group of high scoring intuitive types approached the task with enthusiasm, finding working together 'stimulating', and immediately began to discuss the nature of the task rather than follow it through. They discussed their preference for preaching on the first chapter of John's Gospel rather than the second chapter of Luke's Gospel. They discussed the general principle of how the Bible speaks to them rather than the content of the Lucan birth narrative. They wanted then to change the question to become: what do you see in this passage now, and what do you want others to see now? This would leave the options open for a very different interpretation tomorrow or in three years time when the lectionary next presented the passage.

The six members of the group all seemed to see very different things in the passage. They were individually concerned to identify overarching messages. They were individually attracted by different components of the narrative. They focused on different particulars from the narrative to support their individually identified 'big picture'. The six members of the group were more interested in floating their own ideas than in either listening to the ideas advanced by others or convincing others of their own idea.

The group of low scoring intuitive types agonised over who would give feedback before launching into an exploration of the key themes of Luke 2, which they thought included response (the response made in the passage by the shepherds and Mary, as well as the response we make today); heaven touching earth and the glory of God. They readily referenced other Scripture, noting how the passage opened up the whole gospel for them, one member recalling a sermon she had preached on this passage that started with Mary looking back from the foot of the cross on Good Friday. There was significant and repeated talk of pictures, images and terrifying imagery alongside reference to other art forms: painting and music. Whilst identifying how rich the passage was for them, they experienced the burden of wanting to say something new, having done this so many times before. The search for meaning in the passage was exemplified by one participant imagining Joseph and Mary reflecting after a period of 
breathless activity and wondering 'what was all that about?' Interestingly, when the group started to investigate context, they lost sight of the original brief that it was the first Sunday after Christmas and began to speak of Midnight Mass.

The group of low scoring sensing types approached the task in a matter of fact and business-like manner, finding working together comfortable, even too comfortable one participant considered. Their first job was to be clear about the context in which they were going to preach. The first Sunday after Christmas is an occasion for preaching to the core committed members of the Church. Here effectively is the start of a new phase in the Christian year and a time to motivate the core committed members into action. In this light, the second chapter of Luke's Gospel is about proclaiming the good news of Jesus' birth to others.

Luke 2 is about how the angel of the Lord brought good news of great joy to the shepherds. Luke 2 is about how the shepherds discussed the good news amongst themselves and then went off to see for themselves. Luke 2 is about how the shepherds went back home and about how they told others about what they had heard and what they had seen. The message is that, as Christians, we need to get out, we need to get on with the job, and we need to tell others about the birth of Jesus.

The group of high scoring sensing types divided over the significance of the symbolism of the passage. One participant was concerned to approach the passage as a historian reading Luke's narration of a historical event, whilst another was concerned to stress that grammar and syntax limited interpretations of the passage, considering scripture should be read like a legal document with reference to the author's original intention, which they considered was plain. The group identified itself as consisting of sensing types, but with church tradition issues providing an additional layer, resulting in the group deviating from the task, a situation remedied by one participant who had carefully copied the question and reminded group members of it. The group were observed to consult the passage carefully in search of further inspiration.

\section{Judging process}

\section{Procedure}

The participants were divided into four groups: seven participants who recorded highest preferences on thinking $(45,41,35,27,19,17,17)$; eight participants who recorded highest preferences on feeling $(35,31,29,27,25,23,21,21)$; six participants who recorded lower preferences on feeling $(15,13,7,7,7,7)$, and six participants who recorded lower preferences on thinking $(13,7,3)$ or very low preferences on feeling $(1,1,1)$. The participants were invited to read Matthew 2:13-20 and to reflect on the following task: this is the first Sunday after Epiphany, the magi have moved on, and you are preaching on the aftermath of their visit. What issues does this message raise for you, and what issues do you want it to raise for your congregation? What contextual factors may you wish to take into account? The analysis concentrates on each of these four groups in turn.

\section{Thinking types}

The group of high scoring thinking types began by analysing the questions raised by the task. Some maintained that they generally do not distinguish between the issues raised for themselves and the issues that they wish to raise for the congregation. Others take the view that they distinguished clearly between what they personally found of key interest in the text and what they anticipated to be of interest to their congregation.

Following their introduction, individual members of the group identified the issues that the text raised for them. These issues, identified with a sense of clinical detachment, included:

- how prophecy works

- how God has an overview of history

- how God uses dreams to communicate

- why Herod selected all children under the age of two and how this may help us to date the visit of the magi

- God's care in letting the holy family know when it is safe to return

- how old was Jesus when the family moved back from Egypt

- what kind of person Herod really was

- how God uses astrology to lead people to Christ

- the theme of kingship in Matthew's gospel.

Then the group began to tackle what they saw to be the more profound issues. For one member of the group, the key issue concerned refugees and asylum seekers. Knowledge that Jesus had himself been a refugee and asylum seeker should shape the way we perceive refugees and asylum seekers and should motivate us to challenge the ways in which some of the newspapers present the issue. For a second member of the group, the key issue concerned the comparison between Jesus being saved and the other children being killed. For a third member of the group, the key issue concerned the connection between this narrative and other narratives in the Old Testament: Moses survived the massacre of the innocent children, was called out of Egypt, and led God's people to salvation.

For a whilst discussion settled onto the kind of God who would allow children to be massacred. Bethlehem may not have been a large place and so the slaughter may not have been great. Yet behind all this are the theological problems of evil and free will.

The question about contextual factors was initially understood to refer to the context of wider biblical themes like salvation, history and the kingship of Christ. Then some saw the wider context in national terms: preaching on this text in Zimbabwe would be quite different from preaching on it in suburban England. Little attempt, however, was made to locate the passage in the local congregation and related to the issues of individual people. 
Overall very little passion was engendered in this group and the sheer horror and brutality of the narrative seemed to leave the participants unaffected. The task was nicely completed within the allocated time.

The group of lower scoring feeling types started out by considering the people in the narrative. They considered the suffering experienced by Jesus, Mary and Joseph. They considered the anxiety and insecurity felt by Herod that drove him to such extreme action. They considered the feelings of the parents whose infants were slaughtered. They considered the way in which these parents would respond to Jesus later in life, challenging him that he survived whilst their children had not done so.

The group considered the motivation of the wise men, how they had responded to God's leading, but then got it wrong. They considered how the wise men might have been overrun with feelings of guilt when they discovered how their mistake had been so costly to others.

The group considered how the Feast of the Holy Innocents had been used by one church to hold a special service to remember children who had died in the past year and to support their parents. The hearts of the group went out to parents who had suffered such a great loss.

The group was greatly energised by the process and members were reluctant to draw things to a close.

The group comprising low scoring feeling types and low scoring thinking types began by exploring who had previously preached on the passage. None had done so and there was general agreement that this had not been a passage of choice. Someone maintained that it was not really the lectionary reading for the first Sunday after Epiphany anyway.

The group was captured by the horrid and horrendous nature of the passage. They felt for people in the story, for Jesus, Mary and Joseph and for the victims of Herod's brutality. They felt for the people in the congregation and especially for any who had experienced the death of a child. They could understand such parents walking out during the reading and not staying around to listen to the sermon. They agreed that, however much good news they might be able to preach from the passage, having heard the story the congregation would go away burdened.

The group moved away from the narrative to the setting of reading and proclaiming the passage so soon after the Christmas celebrations. They reflected how Christmas itself can be a brutal season for so many people, involving family arguments, family break-up, and brutality shown to children and animals.

The group of high scoring feeling types commenced by reading the passage aloud. This was followed by a period of profound silence as the force of the emotions was experienced and reflected upon, more remarkable in a group dominated by high scoring extraverts. The first spoken response recounted how very recently she had presented the story in an infant school, underlining how precious Jesus was and how God sought to protect him. This, she suggested, might be an appropriate model for an adult congregation. But, others thought this was really ducking the issue. However tempting it might be for preachers to skip over the murder, it was the murder that leapt off the page and needed to be addressed.

Many links were suggested to try and make sense of this appalling narrative. Deaths in the school in Breslan, the repeated attempts on Jesus' own life; victims of inner city gangs, most notably Stephen Lawrence; the Holocaust; and children in the two-thirds world dying every three seconds whilst 'we' spend money on Trident. A number of these connections were referenced not as academic parallels but as analogous situations that aroused equal compassion and anger amongst the group. The group were aware that they might have someone in their congregation whose child had been killed in a car crash and were demanding to know why God had not spared them.

Another central question for the group was to identify who was responsible for the massacre. Opinion varied. One claimed a Calvinist view in which God ultimately is responsible for everything; another noted how the wise men had gone astray in consulting Herod, an example of how good men even with the right motives can bring about terrible unforeseen consequences; whilst yet another felt this was an easier passage than the account of the fall of Jericho in which God ordered the destruction whilst this was an example of man's inhumanity to man.

The group was clearly energised by the exercise and affirmed as much in feedback. Ideas continued to flow throughout the study, but whilst the mood was extremely good humoured, the pain of empathising with the issues raised by the passage were rarely far away. One person confessed to being 'emotional' reading the passage, whilst another wanted to know if other families got out and maintained that it would be horrible to think that no one else was warned.

The group began to speak of their preaching style. One reported going for empathy, the human, putting yourself in the same place, as their preferred style. A second said she would quite easily use narrative or story every time in preaching, noting how her congregation responded with the comment: you make people come alive. A third maintained that he would speak about my struggles, my feelings, whilst another considered she would use an elucidation of her feelings as a springboard into the remainder of the sermon.

The group was also exercised by the flight of the Holy Family. The immediacy of getting up in the middle of the night struck one person, as he likened it to someone leaving a violent partner. It was noted that Matthew was writing for a Jewish audience, with the deliberate parallels with the Exodus, Moses and the Passover. It was suggested that Jesus was saved because of the obedience of Joseph to his dream, 
but this worried others who were concerned about children who had lost their lives despite their parents' obedience. One contributor, voicing the leitmotif of the discussion, reminded the group that the episode was from antiquity known as the massacre of the Innocents. This was its most disturbing feature, not least because the incarnate God although a refugee with an army at his back, was very pointedly not present on this occasion of suffering.

Despite very evident levels of discomfort with the text, the group professed enjoying working together, and when one member proclaimed: I would like to do this (i.e. prepare to preach in a group of like minded individuals) every week, the suggestion was widely endorsed.

\section{Conclusion}

The present study set out to build on five pioneering studies that had employed a qualitative research tradition to examine the empirical bases for the SIFT method of biblical hermeneutics and liturgical preaching by inviting preachers (who were largely naive about the SIFT method) to reflect on given passages of scripture within working groups that drew together individuals who shared the same psychological type preference. In the first study, Francis (2010) examined the responses of two groups of Anglican preachers (24 licensed readers in England and 22 licensed clergy in Northern Ireland) who reflected on the Marcan feeding of the five thousand (Mk 6:34-44). In the second study, Francis and Jones (2011) examined the responses of two groups of preachers (26 ministry training candidates and 21 Anglican clergy and readers) who reflected on the resurrection narratives presented in Mark 16:1-8 and Matthew 28:1-15. In the third study, Francis (2012a) examined the responses of three groups (a group of 31 Anglican clergy, a group of 16 clergy and lay preachers, and a mixed group of 47 lay people and clergy) who reflected on the Marcan cleansing of the temple and the incident of the fig tree (Mk 11:11-21). In the fourth study, Francis (2012b) examined the responses of two groups of ministry training candidates (one group of 19 and one group of 7) who reflected on the Johannine feeding narrative. In the fifth study, Francis (2013) examined the responses of 8 ordinary readers who reflected on the Marcan and Lucan accounts of John the Baptist. The present study added to the growing body of knowledge by inviting two further groups of preachers (training incumbents and curates) to reflect on the birth narratives presented in Luke 2:8-16 and Matthew 2:13-20. Three main conclusions can be drawn from this growing body of qualitative research.

The first conclusion concerns the psychological theory that underpins the SIFT method. This theory posits that the ways in which individuals read, reflect on and interpret scripture reflect their own personal psychological preferences. The data from all four studies support this psychological theory. In reading text, sensing types really do take trouble over the details, intuitive types really do grasp the bigger vision, feeling types really do give priority to the personal and interpersonal implications, and thinking types really do go for an analysis of the issues raised. Clearly a reader perspective on biblical hermeneutics is incomplete if the contribution of psychological type theory is not taken into account.

The second conclusion concerns the theological principles that underpin the SIFT method. These principles posit that the four key psychological functions of sensing, intuition, feeling, and thinking reflect the richness of individual differences that are part of the intentionality of the divine creator and that are embedded within the rich image of God in whose image human beings are themselves created. This view posits that when the people of God corporately approach the word of God they need to attend to all of the four perspectives generated from the four psychological functions. In other words, the hermeneutical process is incomplete without taking seriously this range of voices. The data from all four studies support these theological principles by demonstrating that the four voices are indeed distinctive and complementary.

The third conclusion concerns the practical out-working of the SIFT method within the personal and professional development of those who hold responsibility for reading, interpreting and proclaiming Scripture amongst the assembled people of God (e.g. preachers within congregations). Where preaching so often remains within the hands of individual leaders, preachers need their awareness raised of the four distinctive voices of the hermeneutical process advocated by the SIFT method (sensing, intuition, feeling and thinking). It is important for preachers to be trained to approach scripture through their less preferred psychological type functions as well as through their dominant function. Experience-based workshops like those employed in the present study provide one efficient and effective method for implementing this kind of practical training.

Two main limitations still remain with the present state of empirical research in this field. When all these studies are considered together, only four biblical themes were explored; and only eight groups of preachers were involved in the research. These two limitations need to be addressed by further replication studies capable of extending the range of scripture employed and capable of working with other groups of preachers. The present study suggests that further research of this nature is likely to illustrate more fully the link between psychological type preferences and hermeneutical approaches (Francis 2010:5 of 5).

\section{Acknowledgements Competing interests}

The authors declare that they have no financial or personal relationship(s) that may have inappropriately influenced them in writing this article.

\section{Authors' contributions}

The authors L.J.F. (University of Warwick) and G.S. (University of Warwick) shared equally in the process 
of generating and analysing the original empirical data employed in this study. L.J.F., as first author, took the lead in developing the theoretical framework within which these data are set.

\section{References}

Bassett, R.L., Mathewson, K. \& Gailitis, A., 1993, 'Recognising the person in biblical interpretation: An empirical study', Journal of Psychology and Christianity 12 38-46. http://dx.doi.org/10.1080/1361767990200109

Cartledge, M.J., 1999, 'Empirical theology: Inter- or intra- disciplinary?' Journal of Beliefs and Values 20, 98-104. http://dx.doi.org/10.1080/1361767990200109

Francis, L.J., 1997, Personality type and scripture: Exploring Mark's Gospel, Mowbray, London.

Francis, L.J., 2005, Faith and psychology: Personality, religion and the individual, Darton, Longman and Todd, London.

Francis, L.J., 2010, 'Five loaves and two fishes: An empirical study in psychological type and biblical hermeneutics among Anglican preachers', HTS Teologiese Studies/ Theological Studies 66(1), Art. \#811, 5 pages. http://dx.doi.org/10.4102/hts. v66i1.811

Francis, L.J., 2012a, 'What happened to the fig tree? An empirical study in psychological type and biblical hermeneutics', Mental Health, Religion and Culture 15(9), 873-891. http://dx.doi.org/10.1080/13674676.2012.676252

Francis, L.J., 2012b, 'Interpreting and responding to the Johannine feeding narrative: An empirical study in the SIFT hermeneutical method amongst Anglican ministry training candidates', HTS Teologiese Studies/Theological Studies 68(1), Art. \#1205, 9 pages. http://dx.doi.org/10.4102/hts.v68i1.1205
Francis, L.J., 2013, 'Ordinary readers and reader perspective on sacred text: Drawing on empirical theology and Jungian psychology', in J. Astley \& L.J. Francis (eds.), Exploring ordinary theology: Dimensions of everyday Christian existence and the life of the Church, pp. 87-96, Ashgate, Farnham.

Francis, L.J., Craig, C.L., Whinney, M., Tilley, D. \& Slater, P., 2007, 'Psychological profiling of Anglican clergy in England: Employing Jungian typology to interpret diversity, strengths, and potential weaknesses in ministry', International Journal of Practical Theology 11, 266-284. http://dx.doi.org/10.1515/IJPT.2007.17

Francis, L.J. \& Jones, S.H., 1999, 'The scale properties of the MBTI Form G (Anglicised) among adult churchgoers', Pastoral Sciences 18, 107-126.

Francis, L.J. \& Jones, S.H., 2011, 'Reading and proclaiming the resurrection: An empirical study in psychological type theory among trainee and experienced preachers employing Mark 16 and Matthew 28', Journal of Empirical Theology 24, 1-18. http://dx.doi.org/10.1163/157092511X571141

Francis, L.J., Robbins, A. \& Village, A., 2009, 'Psychological type and the pulpit: An empirical enquiry concerning preachers and the SIFT method of biblical hermeneutics', HTS Teologiese Studies/Theological Studies 65(1), Art. \#161, 7 pages. http://dx.doi. org/10.4102/hts.v65i1.161

Francis, L.J. \& Village, A., 2008, Preaching with all our souls, Continuum, London.

Jung, C.G., 1971, Psychological types: The collected works, vol. 6, Routledge and Kegan Paul, London. PMid:5290651

Keirsey, D. \& Bates, M., 1978, Please understand me, Prometheus Nemesis, Del Mar, CA.

Myers, I.B. \& McCaulley, M.H. 1985, Manual: A guide to the development and use of the Myers-Briggs Type Indicator, Consulting Psychologists Press, Palo Alto, CA.

Village, A., 2010, 'Psychological type and biblical interpretation among Anglican clergy in the UK', Journal of Empirical Theology 23, 179-200. http://dx.doi.org/10.1163/ $157092510 \times 527349$

Village, A. \& Francis, L.J., 2005, 'The relationship of psychological type preferences to biblical interpretation', Journal of Empirical Theology 18(1), 74-89. http://dx.doi. org/10.1163/1570925054048929 


\section{Appendix 1}

\section{Luke 2:8-20}

In that region there were shepherds living in the fields, keeping watch over their flock by night. Then an angel of the Lord stood before them, and the glory of the Lord shone around them, and they were terrified. But the angel said to them, 'Do not be afraid; for see - I am bringing you good news of great joy for all the people: to you is born this day in the city of David a Saviour, who is the Messiah, the Lord. This will be a sign for you: you will find a child wrapped in bands of cloth and lying in a manger.' And suddenly there was with the angel a multitude of the heavenly host, praising God and saying, 'Glory to God in the highest heaven, and on earth peace among those whom he favours!' When the angels had left them and gone into heaven, the shepherds said to one another, 'Let us go now to Bethlehem and see this thing that has taken place, which the Lord has made known to us.' So they went with haste and found Mary and Joseph, and the child lying in the manger. When they saw this, they made known what had been told them about this child; and all who heard it were amazed at what the shepherds told them. But Mary treasured all these words and pondered them in her heart. The shepherds returned, glorifying and praising God for all they had heard and seen, as it had been told them.

New Revised Standard Version Bible, copyright 1989, Division of Christian Education of the National Council of the Churches of Christ in the United States of America. Used by permission. All rights reserved. 


\section{Appendix 2}

\section{Matthew 2:13-20}

Now after they had left, an angel of the Lord appeared to Joseph in a dream and said, 'Get up, take the child and his mother, and flee to Egypt, and remain there until I tell you; for Herod is about to search for the child, to destroy him.' Then Joseph got up, took the child and his mother by night, and went to Egypt, and remained there until the death of Herod. This was to fulfill what had been spoken by the Lord through the prophet, 'Out of Egypt I have called my son.' When Herod saw that he had been tricked by the wise men, he was infuriated, and he sent and killed all the children in and around Bethlehem who were two years old or under, according to the time that he had learned from the wise men. Then was fulfilled what had been spoken through the prophet Jeremiah: 'A voice was heard in Ramah, wailing and loud lamentation, Rachel weeping for her children; she refused to be consoled, because they are no more.'

When Herod died, an angel of the Lord suddenly appeared in a dream to Joseph in Egypt and said, 'Get up, take the child and his mother, and go to the land of Israel, for those who were seeking the child's life are dead.'

New Revised Standard Version Bible, copyright 1989, Division of Christian Education of the National Council of the Churches of Christ in the United States of America. Used by permission. All rights reserved. 